\title{
UTILIZATION OF DEBT COLLECTOR SERVICES IN DEBT SECURED WITH FIDUSIA IN PANDEMIC PERIOD AFTER THE VERDICT OF THE CONSTITUTIONAL COURT NO. 18/PUU-XVII/2019
}

\author{
Fani Martiawan Kumara Putra \\ Fakultas Hukum Universitas Wijaya Kusuma Surabaya \\ e-mail: fanimartiawan@gmail.com
}

\begin{abstract}
Fiduciary guarantee institutions are guarantee institutions that are in great demand in Indonesia, in fact it is very possible that Fiduciary is currently the most widely used guarantee institution besides three other security institutions in Indonesia, namely Gadai, Hipotek and Hak Tanggungan. Determination when the default debtor, has its own rules, can not be interpreted arbitrarily, then in a pandemic like this, determining the default debtor certainly also needs to consider the economic conditions of many parties that decline, then it means, whether the use of debt collectors is still a matter that is worthy of attention to these two aspects. This is a normative legal research. The result of this research is that the Constitutional Court's ruling drew many interpretations, one form of which was that the Fiduciary guarantee was no longer familiar with parate executies, and sales were underhanded, but had to go through the court. Even though the decree also emphasized default. This decision must be interpreted in full, not only related not to execute it, but also to understand about the default. Thus, will be clear what the purpose of the ruling of the constitutional court. This will also be useful for law enforcement on the civil debt relationship during this pandemic. Leasing as an institution that provides credit to the public, still requires classification rules for customers who can apply for credit. So that cases of customers who are negligent in debt payments and have problems with debt collectors do not occur.
\end{abstract}

Keywords: Fiduciary; Pandemic; Debt Collector; Constitutional Court

\section{INTRODUCTION}

Debt are always based on an agreement that is an agreement between the party that gives the debt (the creditor) and the party that owes (the debtor). Accounts payable are accompanied by guarantees as safeguards. If the debtor is negligent in paying debts (default) to the creditor, the collateral can be used as a source of credit repayment. In other words, the guarantee must be able to protect the debt and credit agreement so that in the future no one will suffer losses.
Of course, objects that can be used as collateral are valuable objects, in the sense of objects that have economic value and can be transferred. In addition, the object must be bound in a material guarantee agreement, then registered with the relevant guarantee agency.

Fiduciary guarantee institutions are guarantee institutions that are in great demand in Indonesia, in fact it is very possible that Fiduciary is currently the most widely used guarantee institution besides 
3 (three) other guarantee institutions in Indonesia, namely Gadai, Hipotek and Hak Tanggungan.

Fidusia can occupy this position because of the ease of the process of loading the guarantee and the unique character of the Fiduciary guarantee itself, that is, the collateral is in the possession of the debtor. Given the pattern of people who more often choose to owe when they have urgent needs, and the money released by creditors needs to be secured or protected.

One area of business that relies heavily on the smooth operation of its Fiduciary guarantee, is in the field of motor vehicle loans, whether through leasing, or bank debt. In accordance with its character, the guarantee institution is Fidusia, because the real object secured is the motorized vehicle controlled by the debtor, then the certificate of ownership is held by the creditor. This is clearly not a Gadai, but Fidusia.

In a motorcycle loan system, many credit payments do not work as it should. Violation of the credit agreement, where the buyer should pay the monthly installments, but in fact this agreement is not executed. Then many creditors use the services of third parties (debt collectors) to collect and even withdraw motor vehicle units. The provisions of Article 1792-1819 Burgerlijk Wetboek, emphasized that with a power of attorney, debt collection services can represent creditors to collect debts.

Trends occurring in practice often occur violations of the law because the debt collector does his job by force, and often accompanied by an element of violence that results in the confiscation of the debtor's motorized vehicle.

The confiscation of a motorized vehicle is considered to be an arbitrary execution of collateral. Then the Constitutional Court Decision Number 18/ PPU-XVII/2019 states that the creditors may not carry out their own execution but submit a request to the District Court if the debtor does not recognize the existence of default, and is not willing to hand over fiduciary objects voluntarily.

Determination when the default debtor, has its own rules, can not be interpreted arbitrarily, then in a pandemic like this, determining the default debtor certainly also needs to consider the economic conditions of many parties that decline, then it means, whether the use of debt collectors is still a matter that is worthy of attention to these two aspects.

\section{PROBLEM FORMULATION}

Utilization of Debt Collector Services in Debt Secured with Fidusia In Pandemic Period After the Verdict of The Constitutional Court No. 18/PUUXVII/2019.

\section{RESEARCH METHOD}

This research is a normative research with statute approach, which means the findings and discussion done in this research are based on Indonesian law regulation, and the problematic are caused by the lack of Indonesian law regulation. This research is not based on social respond that came from a law regulation.

\section{DISCUSSION}

Objects in law in Indonesia are regulated in the Burgerlijk Wetbook (BW), namely Book II on Objects (Van Zaken). Objects are placed in Book II BW, because Book I BW regulates about People, and the thing closest to people, it is Objects, therefore Objects are placed in Book II BW by the Author BW. Based on Article 499 BW, what is meant by objects (zaken) is each item (goederen) and every right (rechten) that can be the object of ownership rights. Means that an object is an object, or object, material that is tangible and always followed by property rights wherever the object is located.

The existence of objects or zaak in Indonesia is known in the field of the law of objects itself, but also known in the field of law of stomachangan. Objects in the realm of property law means that objects are always followed by surrender and become objects of property rights. In addition, objects according to the field of the law of abiding means that the object is used as a means of delivery where the object has a value so that it can be used as a verbintenic object. $^{1}$ Because the validity of an agreement, one of which is the existence of an object, therefore the existence of an object can also be used as an object of view. But indeed, the objects in the ventral field are more extensive in existence, because in the case of ventilation is usually done with an open system. The point is that in this case everyone can enter into an agreement regarding anything that has been regulated in the Law or where there is no regulation. In fact,

\footnotetext{
${ }^{1}$ Sri Soedewi Masjchoen Sofwan. (1974). Hukum Perdata: Hukum Benda. Yogyakarta: Liberty, h. 17.
} 
when referring to the systematic regulation of objects in Indonesian law, the rules are (dwingend recht) or compelling, and are closed. This means that anyone cannot determine new rules regarding material other than those regulated in law. This means that every person who commits any legal action involving objects must pay attention to all the rules regarding material that have been determined. ${ }^{2}$

In accordance with the nature of property law in Indonesia which is closed and coercive, in it contains all the arrangements regarding objects starting from the definition of the object itself, the differentiation of various types of objects, to various material rights. In an object, what is attached is called a material right, which is the right to an object.

Material rights are rights that give direct power over an object and can be defended against anyone who has inherent characteristics. In other words, material rights give absolute power over an object. Material rights can be divided into 2 (two) types, namely:

1. Material rights that provide enjoyment, this right means that it aims to provide enjoyment of both one's own objects and those of others. These rights such as property rights, rights to build, right to cultivate;

2. Material rights that provide guarantees, these rights are property security rights such as liens for movable objects.

Considering that there are two types of material rights, in one object there can be two property rights, for example a car becomes A's property, which is then because the car's debt-receivables agreement is legally guaranteed to $\mathrm{B}$, the car is not only attached to property rights. to A, also inherent security rights to $\mathrm{B}$.

In any business transaction certainly involves valuable objects. A valuable object that is in great demand will definitely have a high value or price. Given that humans are known as homo economics, which means that human life is always associated with business activities. ${ }^{3}$ And these business activities often involve objects which are also of economic value.

2 Moch. Isnaeni. (2017). Pengantar Hukum Jaminan Kebendaan. Yogyakarta: LaksBang PressIndo, h. 5.

${ }^{3}$ Ibid., h. 10.
Economic value objects mean objects which have quantity or the objects can be valued at the price. That way people will look for opportunities by doing business for profit by using these economic value objects as traded tools or as objects of transactions. So that in the business world which generally always involves objects, of course these objects are often transferable. Transferability always relates to ownership rights over the object. The change of ownership rights to a moving object is a form of business activity if the business activity is carried out using objects as the object of the transaction. So that in the transaction activity it is clear that the object or object being transacted must meet 2 (two) requirements, namely having economic value and the property being transferable. ${ }^{4}$

Transaction activities in business are not merely buying and selling, such as transactions with a debt agreement system which usually always requires objects of economic value and of course can be transferred as objects that will later be used as collateral for the debt. As stipulated in Article 1131 BW which states that all debtor's items, both movable and immovable, both existing and new ones will exist at a later date, shall be borne by all corporate engagements. This is called a general guarantee. It means that the existence of the debtor's object is very important to provide protection to the creditor if the debtor is negligent in paying off his debts because the debtor's collateral assets can be used as debt repayment. Nevertheless, from the Article it is clear that not just any object will be used to pay off debtor's debt, because the way to pay it is execution. When executed means being sold, being sold means there is transfer of ownership rights, and being sold also means that the object can be valued in money. This means that through Article $1131 \mathrm{BW}$ it becomes clear that the interpretation that objects as objects of transactions are objects that have economic value and can be transferred, objects that have these characteristics, are objects in business traffic, supporting the business of business actors.

The term guarantee is a translation from the Dutch language, namely zekerheid or cautie (Zekerheidsrechten) means right, so Zekerheidsrechten is guarantee rights. Guarantees in general mean the ways that creditors guarantee the

${ }^{4}$ Ibid. 
fulfillment of their claims in addition to the general liability of the debtor for his debts, besides that, guarantees are something that is given to creditors to create confidence that the debtor will fulfill moneyvalued obligations arising from an engagement. ${ }^{5}$ In other words, guarantees are legal provisions governing collateral in general, meaning collateral for creditor bills for debtor debt.

The word guarantee can be found in Article $1131 \mathrm{BW}$ and the explanation of Article 8 of the Banking Law, however in both regulations it does not explain what is meant by guarantee. In Article 8 of the Banking Law the explanation of this collateral is known as collateral for credit, which is one of the elements of crediting here is collateral. So that in fact in the Banking Law it is better known as collateral not guarantee. Where further explanation regarding collateral according to Article 1 number 23 of the Collateral Banking Law is further divided into principal collateral and additional collateral. Nevertheless, guarantees are closely related to debt problems. So that the granting of a guarantee agreement is always followed by an agreement that precedes it, namely a debt agreement. Means that guarantee is an activity that arises from an agreement between the party giving the debt or loan (creditor) and the party owing or receiving the loan (debtor). This guarantee exists as a protection for creditors if the debtor is unable to pay off the debt or as a means of guaranteeing the fulfillment of the debtor's debt in case of default before the maturity of the loan or the debt ends.

There are two kinds of guarantees in Indonesia, namely material guarantees (as regulated in Book II BW) and individual guarantees (which are regulated in Book III BW). Material guarantees are guarantees for certain items belonging to the debtor or belonging to third parties specifically designated for the benefit of creditors. Where in this material guarantee that is born in the material agreement are material rights. Meanwhile, individual security is known as coverage, the object of which is achievement, and the rights that are born are relative rights. In addition, it is also known as the distribution of general guarantees and special guarantees, where with this special guarantee to prevent any risks that will occur. Where

\footnotetext{
5 Salim HS. (2004). Perkembangan Hukum Jaminan di Indonesia. Jakarta: Raja Grafindo Persada, h. 22.
}

this particular collateral is the collateral object is a certain object (specifically) owned by the debtor that is intended for creditors. In other words, it is referred to as material guarantee which gives birth to a material agreement where there is an agreement that the debtor agrees to hand over certain objects of his to the creditor to be tied specifically to guarantee the amount of debt the debtor wants. ${ }^{6}$

Collateral by using objects also needs to be distinguished. Differentiation of the objects that are used as the object of guarantee is very necessary because later it can have different consequences in various aspects, therefore we need a way to distinguish these objects, namely the existence of a guarantee institution. The existence of this material guarantee agency in Indonesia is a tracker of the imposition of the objects in question. So that the existence of this guarantee institution is very important because it is a special institution formed by the government with the intention that the objects which are used as objects of the guarantee have clarity or legal certainty.

Fiduciary is one of the guarantee institutions in Indonesia. according to the origin of the word comes from the word "fides" which means belief. In accordance with the meaning of this word, the (legal) relationship between the debtor (the Fiduciary) and the creditor (the Fiduciary's recipient) is a relationship based on trust. The Fiduciary Guarantee Institution was well known and enforced in Roman legal society. There are 2 (two) forms of Fiduciary collateral, namely Fiduciary cum creditore and Fiduciary cum amico. Both arise from an agreement called pactum fiduciae which is then followed by the transfer of rights or in iure cession. ${ }^{7}$

Fiduciary Cum Creditore Contracta which means a trust promise made with a creditor, in this case the debtor will transfer his ownership of an object to the creditor as collateral for the debt by agreement that the debtor will still physically control the object and the creditor will transfer the ownership back to the debtor if the debt already paid in full. ${ }^{8}$

Fiduciary Cum Amico Contracta, which means a promise of trust made with friends, in this form of guarantee a person known as pater familias will entrust his family (family and all his wealth)

\footnotetext{
${ }^{6}$ Moch. Isnaeni. op.cit., h. 93.

7 Ibid.

${ }^{8}$ Ibid.
} 
to a friend who will then take care of his land and wealth and provide guidance and protection to the familias pater. This safekeeping action was carried out because the familias priest had to leave his family and land for a long period of time, either because of long trips or because of going to war. This care was followed by a promise between the family priest and his friend that the friend would return the ownership of the familias to the familias pater when he returned from his trip. Both of these forms of guarantee arise from an agreement called "pactum fidusiae" which is then followed by the transfer of rights "in iure cessio". ${ }^{9}$

Fiduciary is a term that has long been known in Indonesian. The law specifically regulates this matter, namely Law Number 42 of 1999 concerning Fiduciary Security (hereinafter referred to as UUJF), also uses the term "Fiduciary". Thus, the term "Fiduciary" is already an official term in our world of law.

However, sometimes in Indonesian for Fiduciary it is also referred to as "Transfer of Property in Trust". In Dutch terminology it is often referred to by the full term in the form of Fiduciare Eigendom Overdracht, while in full English it is often referred to as Fiduciary Transfer of Ownership.

This is also mentioned in Article 1 number 1 UUJF, that Fiduciary is the transfer of ownership rights of an object on the basis of trust, provided that the object whose ownership rights are transferred remains in the control of the owner of the object. Fiduciary Security is the right of collateral for movable objects, both tangible and intangible and immovable objects, especially buildings that cannot be encumbered with Mortgage Rights that remain under the control of the Fiduciary, as collateral for the repayment of certain debts, giving priority to the Fiduciary. against other creditors (Article 1 point 2 UUJF).

The material guarantee institution as above, considering that the rules are in positive law in Indonesia, then of course it gives birth to the right to material security. The characteristics of the material security rights contained in Fiduciary include:

1. Droit De Suite Principle. This principle is contained in Article 20 of the UUJF which states that the Fiduciary Guarantee follows the object

${ }^{9}$ Ibid. which is the object of the Fiduciary Guarantee in the hands of whoever the object is in;

2. Principles of Droit De Preference. This principle is contained in Article 1 point 2 of the UUJF which states that the position of the creditor holding the fiduciary security is the preferred creditor, namely as the preferred creditor;

3. Principles of Publicity. In accordance with Article 4 UUJF begins with the making of a principal agreement in the form of a credit agreement or debt agreement. The principal agreement in the form of a credit agreement can be made by deed under hand, meaning that it is made by the Creditors and Debtors themselves or an authentic deed, which means that it is made by and before a notary public.

Then based on Article 5 paragraph 1 UUJF, the imposition of objects with Fiduciary guarantees marked by the making of the Fiduciary Security Deed signed by the creditor as the Fiduciary recipient and the Fiduciary giver must be made with a notarial deed. If you already have a Fiduciary guarantee deed, you can register. Fiduciary security registration is regulated in Article 11 to Article 18 UUJF and Government Regulation Number 86 of 2000 concerning Fiduciary Security Registration Procedures and Fiduciary Security Deed Making Fees (hereinafter referred to as PP Fiduciary Registration). ${ }^{10}$ Registration is a mandatory thing that must be fulfilled as a condition for the birth of the Fiduciary Guarantee. ${ }^{11}$

Principle of Execution. Based on the UUJF, there are 3 (three) ways of executing the fiduciary guarantee, namely: ${ }^{12}$

1. Implementation of the executorial title by fiduciary recipients;

2. Sale of objects that are the object of fiduciary security on the power of the recipient of the fiduciary himself through a public auction; and

3. Underhand sales are carried out based on the agreement of the fiduciary giver and receiver.

The term Debt Collector comes from English, which when translated into Indonesian, namely debt

${ }^{10}$ Ibid.

11 Muhammad Ikhsan Awaljon Putra. (2016). "Eksekusi Terhadap Benda Jaminan Fidusia Yang Tidak Didaftarkan Pada PT. Capella Multidana". Jurnal JOM Fakultas Hukum, Vol. III No. 1 Riau, h. 8.

${ }^{12}$ Ibid., h. 9. 
means debt, collector means collector, examiner, So, debt collectors are a collection of people/groups of people who sell services to collect debts from someone or the institution that rents them. Debt collector is a third party that connects creditors and debtors in terms of collection, such collection can only be done if the quality of the said claims has been included in the category of doubtful collectability or loss.

The Debt Collector works based on the power of attorney from the creditor who previously had a partnership in the Memorandum of Understanding, or commonly called the Memorandum of Understanding (MoU) in terms of debt collection. Article 1792 of the Civil Code explains that granting power of attorney is an agreement whereby a person gives power to another person, who receives it to carry out an affair on his behalf. This may imply that the Debt Collector as a third-party works based on a power of attorney from the creditor concerned in terms of debt collection. So that according to the Article above, the Debt Collector's work is considered valid as long as the billing process is carried out in a manner that is not against the law.

\section{Legal Status of Debt Collectors in Credit Agreements}

The legal relationship between the creditor and the debtor begins when the creditor (leasing) finances the object promised in this case the motorcycle. Leasing as a creditor has an obligation to pay a certain amount of money to the dealer where the motorbike is purchased and then the motorbike can be controlled by the debtor, but in the right to ownership of the motorbike it remains the property of the lease until the debtor repays the agreed credit.

In the world of finance or leasing companies, there is a role for debt collectors, in which debt collectors are third parties who are seconded by finance or leasing companies to settle problem loans that cannot be handled by regular collectors. Debt collection is a third party that connects creditors and debtors in terms of credit collection. Such collection can only be done if the quality of the said credit bill is in the doubtful or loss category.

Regarding the case of bad credit that caused the debtor to default, the financing company sent a warning letter (summons) several times to the debtor.
However, if the warning letter is ignored by the debtor, the finance company will take or confiscate the item with the help of a debt collector. If the debtor pays the debtor's debt installments smoothly, the leasing does not need to require a third party to collect the debtor's debt installments.

This power of attorney needs to be linked to the provisions of Article $1315 \mathrm{BW}$ which states that in general no one can bind himself or herself on behalf of or request the stipulation of a promise except for himself. This article explains the existence of the principle of personality in contracting, meaning that someone who makes an agreement that causes an agreement or contract cannot be in the name of another person, in the sense that the person who bears the obligation and who gets the rights from the agreement is only the party who has entered into the agreement. This provision is related to the provision of power of attorney in BW. However, in article 1317 $\mathrm{BW}$ it is explained again that the provisions of Article $1315 \mathrm{BW}$ may be disregarded if there is a power of attorney from the person on behalf of. Article 1317 BW also explains to allow someone to promise that in the agreement gives rights to a third party, and if the third party has stated that they will use that right, the party that gives the rights to the third party may not withdraw it.

In the agreement, the power of attorney also contains provisions regarding the billing procedure, namely the billing procedure must be in accordance with the provisions set by the finance company and avoid things that are not desirable or outside the provisions set by the finance company, so that if the debt collector in performing work outside of the matter determined by the finance company, this action will be a personal responsibility in this case the debt collector.

The granting of power (lastgeving) is regulated in book III Chapter XVI starting from articles 1792-1819 BW, while the power (volmacht) is not specifically regulated, either in BW or in other legislation, but is described as part of the granting power. $^{13}$

Power occurs because of machtiging, which is a statement of the will (one-sidedly) from the

${ }^{13}$ Herlien Budiono. (2012). Kumpulan Tulisan Hukum Perdata di Bidang Kenotariatan. Bandung: Citra Aditya Bakti, h. 413 . 
power of attorney that contains the desire that he be represented by the recipient of the power to take legal action for the sake of and on behalf of the authorizer. From the statement of the power of attorneys will arises a right for the recipient of the power of attorney not an obligation to take legal action on behalf of the grantor. ${ }^{14}$

The power given by the grantor of attorney is related to the principle of nemo plus iuris ad alium transferre potest quam ipse haberet, which means that a person cannot transfer rights to another person more than the rights he has, so that the power of attorney cannot give more power than rights or authority they have. ${ }^{15}$

It is necessary to pay attention to the general provisions, a power of attorney is private in nature which means that the presence of a power of attorney does not necessarily mean that the person giving the power of attorney cannot carry out the legal action that has been authorized.

Usually leasing employs outsourced debt collectors, this is done because hiring through outsourcing is considered more efficient where using collection services through outsourcing, the leasing party only pays fees according to the debt collector's performance itself. The power of attorney agreement between the lease and the debt collector includes the power of attorney without the intervention of the competent authority in this case a notary public. So that the granting of power like this will only have the power of perfect formal proof as the granting of authentic power if there is no denial of the material (Article $1875 \mathrm{BW}) .^{16}$

The position of the debt collector is the power of the creditors only to collect credit payments from the debtor. However, if the debtor has been proven to have defaulted, the debt collector with the power of the leasing party as the creditor can carry out the execution of the collateral object through the court.

The rights and obligations between the lease and the customer in the motorcycle loan agreement include Rights and Obligations of leasing. The right of leasing as a creditor as a fund provider has the

${ }^{14}$ Taufiq Utomo, dkk. (2017). "Perlindungan Hukum Terhadap Penerima Kuasa Yang Aktanya Dicabut Sepihak Oleh Pemberi Kuasa”. Jurnal Hukum, h. 4.

${ }^{15} \mathrm{Ibid}$.

${ }^{16}$ Eka Astri Maerisa. (2013). Membuat Surat-Surat Bisnis dan Perjanjian. Jakarta: Transmedia Pustaka, h. 236. right to ask for an amount of money to be paid by the customer as a debtor and to receive a credit guarantee as stipulated in article $1131 \mathrm{BW}$ to ensure that the debtor will pay his debt according to a predetermined period of time, BPKB (Motor Vehicle Owner's Book) as collateral from the customer's installments in the loan agreement is kept by the lease to guarantee if the customer reneges on the agreement that has been agreed.

The leasing obligation as a creditor to provide funds for the purchase of motorbikes has the obligation to provide financing and also submit documents in the form of a BPKB which becomes a building or guarantee if the credit is paid off.

The rights of debtors/consumers are contained in article 4 of Law no. 8 of 1999 concerning Consumer Protection which states that consumer rights include consumers the right to be served and treated correctly and honestly, the right to choose and get goods in accordance with the exchange rate and conditions and guarantees promised, the right to correct, clear and honest information regarding the conditions and guarantees of goods, the right to hear their opinions and complaints about the goods used, the right to get advocacy, protection, and efforts to properly resolve consumer protection disputes, the right to receive consumer guidance and education, the right to obtain compensation, compensation and compensation if the goods received are not in accordance with the agreement, the rights regulated in the provisions of other laws and regulations.

Debtor/consumer obligations as customers or borrowers of funds from leasing have an obligation to pay installments in an orderly manner, and fulfill all administrative requirements and consumers must submit a guarantee to the lease.

\section{Legal Relationship Between Creditor and Debt Collector}

The legal relationship between the creditor and the debtor begins when the creditor (leasing) finances the object promised in this case the motorcycle. Leasing has an obligation to pay a certain amount of money to the dealer where the motorbike is purchased and then the motorbike can be controlled by the debtor, in that the right to ownership of the motorbike remains the property of the debtor but leasing as a creditor holds proof of ownership (BPKB) which is 
used as a credit guarantee until the debtor repays the promised credit.

When there is a default made by the debtor as the fiduciary, the leasing authorizes the debt collector to make the debtor carry out his obligations. Default or non-fulfillment of promises can occur either on purpose or accidentally. A debtor is said to be negligent, if he does not fulfill his obligations or is late in fulfilling them but not as promised.

If the debtor in fulfilling his obligations is not in accordance with the agreement in the agreement that has been signed together, then the lease, as the fiduciary/creditor, can ask for help from a third party as a debt collector to carry out his duties on behalf of the lease in matters of collecting debts from the debtor. Thus, the legal position of debt collectors is to represent the lease as the fiduciary/creditor, to deal with the debtor/fiduciary.

The procedure for collection by a debt collector is as follows:

a. Desk collector

At the desk collector level, this level is the first level in the world of collection, and the way this debt collector works is to only remind the due date of the debtor's installments and it is done by telephone. At this level, the collection service only functions as a reminder for debtors for their obligation to pay installments. The language used is very polite and refined, considering his orientation as a customer servant.

b. Debt collector

This level is a continuation of the previous level, if it turns out that the debtor who has been contacted has not made a payment, resulting in a late payment. The way a debt collector at this level is done is to visit the debtor with the hope of knowing the debtor's condition and financial condition. At this level, debt collectors provide a persuasive understanding of the debtor's obligations in terms of making installment payments. The things that are explained are usually about the consequences that can be caused if the late payment is not resolved immediately. Debt collectors also provide an opportunity or grace period no more than seven working days.

Debt collectors are allowed to receive direct payments from the debtor, but what the debtor needs to pay attention to is to ensure that the debtor receives proof of payment from the debt collector, and that evidence is proof of payment from the company where the debtor has a credit obligation, not proof of payment in the form of a receipt that can traded for granted.

c. Collector Remedial

If it turns out that the debtor still has not made the payment, the arrears will be given to the next level, namely the collector remedial. At this level what gives a negative impression about the world of debt collection, because at this level the debt collection system works by taking collateral (if the agreed credit has collateral) the debtor.

\section{Withdrawal of Collateral by Debt Collectors}

Execution as a legal action carried out by the court to the losing party in a case is the rules and procedures for the proceedings of the case investigation. Execution is an integral part of the procedural code of conduct contained in the HIR or RBG. ${ }^{17}$

Execution of fiduciary guarantees as an effort to force the fulfillment of creditors' rights which are part of formal civil law that is included in the realm of civil procedural law. ${ }^{18}$

Provisions regarding the right of Fiduciary Recipients to retrieve goods are contained in the provisions of Article 4 of the Regulation of the Minister of Finance of the Republic of Indonesia Number 130/PMK.010/2012 concerning Registration of Fiduciary Guarantees for Financing Companies (leasing) which carry out consumer financing for motorized vehicles with the imposition of fiduciary guarantees, which states the fiduciary guarantee that the withdrawal of fiduciary collateral in the form of motorized vehicles by a financing company is obliged to comply with the terms and conditions as stipulated in the law concerning fiduciary security and has been agreed by the parties in the motor vehicle consumer financing agreement. ${ }^{19}$

${ }^{17}$ Yahya Harahap. (2013). Ruang Lingkup Permasalahan Eksekusi Bidang Perdata. Jakarta: Sinar Grafika, h. 1.

${ }^{18}$ HFA Vollmar. (1983). Pengantar Studi Hukum Perdata. Jakarta: Rajawali, h. 6.

${ }^{19}$ Yuzrizal. (2015). Aspek Pidana dalam Undang-undang No. 42 Tahun 1999 tentang Jaminan Fidusia. Malang: Media Nusantara Creative, h. 74. 
When withdrawing a motorized vehicle that is guaranteed with a fiduciary guarantee, the recipient of the fiduciary lease provides a copy of the fiduciary guarantee certificate which is submitted to the debtor. With the existence of a fiduciary guarantee certificate, creditors have full rights to execute objects that are the object of fiduciary security. After withdrawing the collateral object, usually the creditor does not immediately conduct the auction or underhand sale. Usually the debtor is called to resolve the problem of arrears in installments. If there is no agreement during the meeting, the creditors will sell the vehicle through auction or under hand sale to pay off the arrears in installments and the remaining debtor's debt.

In executing the fiduciary guarantee, the leasing party as the creditor can actually ask the police for assistance as regulated in the Regulation of the Head of the National Police of the Republic of Indonesia Number 8 of 2011 concerning Securing the Execution of Fiduciary Security, hereinafter referred to as PERKAP No. 8 of 2011. Creditors can submit applications through a proxy the law to the Regional Police Head was then forwarded to the Head of the Regional Police (Kabidkum) of the Regional Police to examine the completeness and validity of the requirements for security applications that were declared to be eligible, the Regional Police ordered the Head of the Operational Bureau to prepare, plan, and carry out security of execution. Due to this complicated procedure, if the execution is deemed manageable and the debtor who controls the cooperative collateral object does not fight or try to block the execution, usually the leasing as the creditor only gives power to the debt collector. Article 9 PERKAP No. 8 of 2011 also explains if the fiduciary recipient appoints a third party to execute the collateral object, so that the debt collector confiscating the fiduciary collateral object is legal in the eyes of the law. Although the Article also explains that all consequences arising from the execution of the fiduciary guarantee are the responsibility of the fiduciary recipient (creditors) and third parties (debt collectors).

The existence of PERKAP No. 8 of 2011 serves as a protection for debtors from being treated arbitrarily by debt collectors as the power of creditors. However, in the implementation in the field, usually the debt collector cannot show the documents that must be brought in the execution of the fiduciary guarantee such as the power of attorney and the fiduciary guarantee deed itself so that the execution is considered legally flawed and the debtor can refuse to submit the object of guarantee. So that the leasing and debt collectors must coordinate and prepare documents before executing so that the implementation is legal before the law.

However, in recent developments there is a Constitutional Court Decision No. 18/PUUXVII/2019, dated January 6, 2020, which states that the recipient of fiduciary rights (creditors) may not carry out the execution by themselves but must submit a request for execution to the District Court. Thus, debt collectors cannot withdraw the motorbike as collateral in the motorcycle loan agreement.

The Constitutional Court's ruling drew many interpretations, one form of which was that the Fiduciary guarantee was no longer familiar with parate executies, and sales were underhanded, but had to go through the court. Even though the decree also emphasized default.

The concept of default here must be emphasized so that the meaning of the Constitutional Court decision does not cause misinterpretation. Default is a condition where the debtor is disabled in performing his performance, but it is necessary to remember when the default occurred. In accordance with Article 1238 BW, a default can occur if:

1. It has been written in the agreement, when the creditor expects achievement, and when at that time he does not carry out the achievement, then it must be considered in default, so that the creditor has the right to sue for the result of default;

2. When there is no explicit written as above, then when the debtor does not perform according to the expectations of the creditor, the creditor needs to provide a summons to the debtor first. A claim that is not properly ignored will put the debtor in default.

Once entered into a state of default, the execution of Fiduciary guarantees can be carried out as is the norm in UUJF, of which there are three ways.

That is, when the debtor is not legally certain that it is in default, to execute the object of collateral must go through the Court, which is actually also a form 
of subpoena, because later of course the Court will summon Debtor, Debtor who is not good faith could provide the basis for the foreclosure. So that this is merely to prevent arbitrariness from the creditors in collecting and confiscating objects of collateral, especially at the Fiduciary guarantee institution.

Regarding default, it is also necessary to pay attention to this during this Pandemic. At a time when the whole world is required to change because almost every aspect of life, especially the economy, is affected by the pandemic, some adjustments to civil law relations are also needed, especially debts.

Such a large impact on the economic aspect of all levels of society, of course, affects the performance of the payment of a debt-receivable agreement, so at least there is a policy from the creditors to understand such conditions, especially for the debtor. So that when there is a debtor who experiences payment difficulties, it does not always mean that the debtor is in default, considering that in default there is bad faith, and it could be that the debtor has good intentions, but due to force majeure then he cannot fulfill his achievement, this can be legal. used to ward off default.

Regarding the decisions of the constitutional court, pandemic conditions, and debt collectors who are the recipients of power from creditors to collect debts, it is appropriate for the law to provide protection to debtors, by limiting the use of debt collectors for debtors who have difficulty paying during the pandemic, and when creditors object, can submit to the Court so that the Judge can give a fair decision to debtors who are in economic trouble due to the pandemic. In order to limit arbitrary creditors during the pandemic as above, it is necessary to provide restrictions in the form of sanctions for arbitrary actions of debt collectors, which originate from the granting of power by the creditors.

\section{CONCLUSION}

The working principle of debt collection is to work based on the power of the creditors in collecting debt as regulated in Article 1792 BW. The Decision of the Constitutional Court No. 18/PUU-XVII/2019, dated January 6, 2020, stated that the recipient of the fiduciary right (creditors) may not carry out the execution by themselves but must submit a request for execution to the District Court. Thus, the debt collector as the creditor's attorney may not withdraw the motorbike as collateral in the motorcycle loan agreement. This decision must be interpreted in full, not only related not to execute it, but also to understand about the default. Thus, will be clear what the purpose of the ruling of the constitutional court. This will also be useful for law enforcement on the civil debt relationship during this pandemic.

\section{RECOMMENDATION}

Leasing as an institution that provides credit to the public, still requires classification rules for customers who can apply for credit. So that cases of customers who are negligent in debt payments and have problems with debt collectors do not occur.

\section{BIBLIOGRAPHY}

\section{Legislation:}

Law Number 42 of 1999 concerning Fiduciary Security.

Burgerlijk Wetbook.

The Constitutional Court No. 18/PUU-XVII/2019.

Regulation of the Minister of Finance of the Republic of Indonesia Number 130/PMK.010/2012 concerning Registration of Fiduciary Guarantees for Financing Companies.

Regulation of the Head of the National Police of the Republic of Indonesia Number 8 of 2011 concerning Securing the Execution of Fiduciary Security.

Constitutional Court Decision No. 18/PUUXVII/2019.

\section{Book:}

Eka Astri Maerisa. (2013). Membuat Surat-Surat Bisnis dan Perjanjian. Jakarta: Transmedia Pustaka.

Herlien Budiono. (2012). Kumpulan Tulisan Hukum Perdata di Bidang Kenotariatan. Bandung: Citra Aditya Bakti.

HFA Vollmar. (1983). Pengantar Studi Hukum Perdata. Jakarta: Rajawali.

Moch. Isnaeni. (2017). Pengantar Hukum Jaminan Kebendaan. Yogyakarta: LaksBang PressIndo.

Rachmadi Usman.

Salim HS. (2004). Perkembangan Hukum Jaminan di Indonesia. Jakarta: Raja Grafindo Persada. 
Sri Soedewi Masjchoen Sofwan. (1974). Hukum Perdata: Hukum Benda. Yogyakarta: Liberty.

Yahya Harahap. (2013). Ruang Lingkup Permasalahan Eksekusi Bidang Perdata. Jakarta: Sinar Grafika.

Yuzrizal. (2015). Aspek Pidana dalam Undangundang No. 42 Tahun 1999 tentang Jaminan Fidusia. Malang: Media Nusantara Creative.

\section{Journal:}

Muhammad Ikhsan Awaljon Putra. (2016). "Eksekusi Terhadap Benda Jaminan Fidusia Yang Tidak Didaftarkan Pada PT. Capella Multidana”. Jurnal JOM Fakultas Hukum, Vol. III No. 1 Riau, h. 8. Taufiq Utomo, dkk. (2017). "Perlindungan Hukum Terhadap Penerima Kuasa Yang Aktanya Dicabut Sepihak Oleh Pemberi Kuasa". Jurnal Hukum, h. 4 . 